
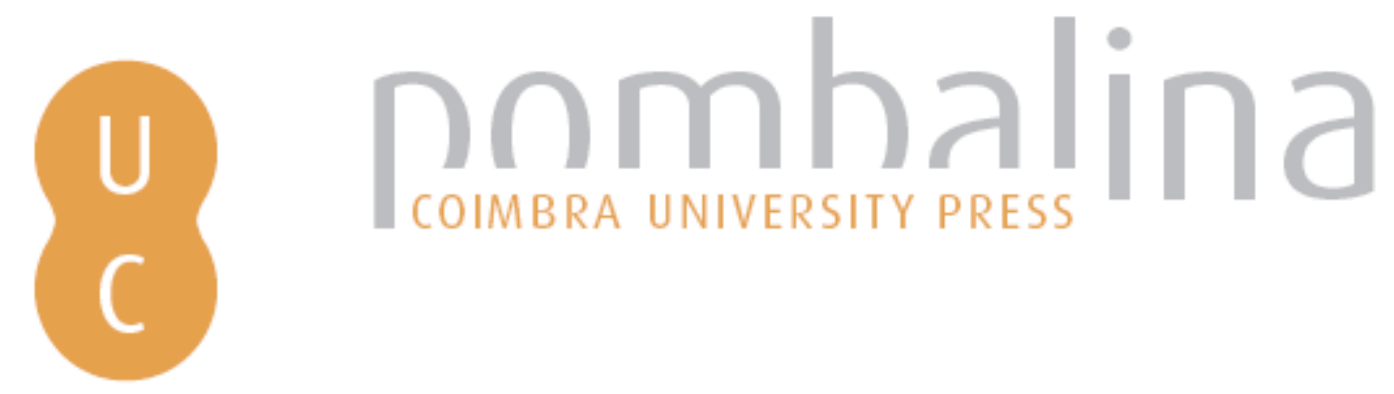

\title{
The Ptolemies: an Unloved and Unknown Dynasty: contributions to a Different Perspective and Approach
}

\author{
Autor(es): $\quad$ Sales, José das Candeias \\ Edições Afrontamento; CITCEM - Centro de Investigação \\ Publicado por: Transdisciplinar «Cultura, Espaço e Memória»; Centro de Estudos \\ Clássicos e Humanísticos; Alexandria University; Imprensa da \\ Universidade de Coimbra \\ URL \\ persistente: \\ URI:http://hdl.handle.net/10316.2/36150 \\ DOI: \\ DOI:http://dx.doi.org/10.14195/978-989-26-0966-9_2 \\ Accessed : $\quad$ 26-Apr-2023 01:26:39
}

A navegação consulta e descarregamento dos títulos inseridos nas Bibliotecas Digitais UC Digitalis, UC Pombalina e UC Impactum, pressupõem a aceitação plena e sem reservas dos Termos e Condições de Uso destas Bibliotecas Digitais, disponíveis em https://digitalis.uc.pt/pt-pt/termos.

Conforme exposto nos referidos Termos e Condições de Uso, o descarregamento de títulos de acesso restrito requer uma licença válida de autorização devendo o utilizador aceder ao(s) documento(s) a partir de um endereço de IP da instituição detentora da supramencionada licença.

Ao utilizador é apenas permitido o descarregamento para uso pessoal, pelo que o emprego do(s) título(s) descarregado(s) para outro fim, designadamente comercial, carece de autorização do respetivo autor ou editor da obra.

Na medida em que todas as obras da UC Digitalis se encontram protegidas pelo Código do Direito de Autor e Direitos Conexos e demais legislação aplicável, toda a cópia, parcial ou total, deste documento, nos casos em que é legalmente admitida, deverá conter ou fazer-se acompanhar por este aviso.

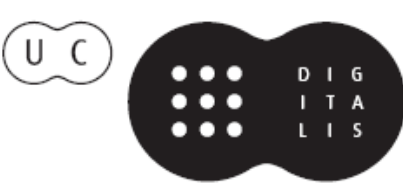




\title{
THE PTOLEMIES: AN UNLOVED AND UNKNOWN DYNASTY. CONTRIBUTIONS TO A DIFFERENT PERSPECTIIVE AND APPROACH
}

\author{
JOSÉ DAS CANDEIAS SALES
}

Universidade Aberta. Centro de História (University of Lisbon).

\begin{abstract}
The fifteen Ptolemies that sat on the throne of Egypt between 305 B.C. (the date of assumption of basileia by Ptolemy I) and 30 B.C. (death of Cleopatra VII) are in most cases little known and, even in its most recognised bibliography, their work has been somewhat overlooked, unappreciated. Although boisterous and sometimes unloved, with the tumultuous and dissolute lives, their unbridled and unrepressed ambitions, the intrigues, the betrayals, the fratricides and the crimes that the members of this dynasty encouraged and practiced, the Ptolemies changed the Egyptian life in some aspects and were responsible for the last Pharaonic monuments which were left us, some of them still considered true masterpieces of Egyptian greatness. The Ptolemaic Period was indeed a paradoxical moment in the History of ancient Egypt, as it was with a genetically foreign dynasty (traditions, language, religion and culture) that the country, with its capital in Alexandria, met a considerable economic prosperity, a significant political and military power and an intense intellectual activity, and finally became part of the world and Mediterranean culture.
\end{abstract}

The fifteen Ptolemies that succeeded to the throne of Egypt between 305 B.C. (date of assumption of basileia by Ptolemy I) and 30 B.C. (death of Cleopatra VII), after Alexander's death and the division of his empire, are, in most cases, very poorly understood by the public and even in the literature on the topic. Their work has been somewhat overlooked, little appreciated and undervalued. 
Despite being undeniable that it was quite turbulent, frenetic and sometimes cruel, and so unloved, with its tumultuous and dissolute lives, the ruthless and unbridled ambitions, the innumerous intrigues and betrayals, the fratricides and the various crimes that its members promoted or practiced, this dynasty changed the Egyptian life in some aspects and was responsible for the last Pharaonic monuments which exist to this day, some of them still considered true masterpieces of Egyptian greatness, authentic ex-libris of the Nilotic civilization. In relation to this, it is enough to mention the divine temples of Horus in Edfu, of Isis in Philae, of Hor-Wer/ Sobek in Kom Ombo, of Khnum in Esna, of Hathor in Dendera and of Mandulis in Kalabsha. Although dating from a very recent period, these monuments are, for most part, a vital link to the earliest Pharaonic Egypt.

This list does not include, of course, other monuments, built or rebuilt under the supervision of the Ptolemies in Medamud, Heliopolis, Sebennytos, Karnak, Saqqara, Qasr el-Aguz, Kom Abu Billo, Behebeit el-Hagar, Tod, Xois, Koptos, Qaw el-Kebir, Dakka, Deir el-Medina, Dabod, Athribis, Armant, or Tanis.

The pictorial, iconographical and architectural grammar, which the Ptolemies produced and reproduced with expressive and explicit canonical images, affiliated these monuments in the tradition and centuries-old Egyptian native form of art of the Ptolemaic Period - supposedly a time of decadence - and make it one of the most sumptuous eras of ancient Egypt in terms of architectural constructions. Except for the Islamic buildings (of various Islamic periods), the last great monuments erected in Egyptian soil have the Ptolemaic seal.

The Ptolemaic Period was, in fact, a paradoxical moment in the history of ancient Egypt, not only due to its architecture, but also because it was in the hands of a genetically foreign dynasty (traditions, language, religion and culture) that the country, with its capital in Alexandria, met a considerable economic prosperity, a significant political and military power and an intense intellectual and artistic activity, and eventually achieved a prominent position in the world and Mediterranean culture ${ }^{1}$.

Thus, as Joe G. Manning recently wrote, it is now necessary, in the name of a proper historical understanding, to rehabilitate the Ptolemaic era as one of the most successful long periods of Egyptian history².

In this sense, there are indeed two or three key ideas about this dynasty, somewhat emphasized or devalued by most researchers, which should be taken into account when approaching the Ptolemaic Period and this dynasty, founded by one of the diadochoi of Alexander the Great.

The first of these ideas can be expressed solely through the statement, easily proved by simply querying chronological lists and tables from the history of ancient Egypt, that the

\footnotetext{
${ }^{1}$ BONACASA, 1995: 67-79.

${ }^{2}$ MANNING, 2010: 31 .
} 
Ptolemaic state was the most durable of the Hellenisticic states established after the death of Alexander and the subsequent fall of his empire. In other words, the Ptolomies were the lasting dynasty of Egyptian history ${ }^{3}$.

This simple conclusion is particularly overlooked by researchers and often unknown by Egyptologists, more focused on other periods of study. It is therefore extremely useful to compare the duration of some of the most important dynasties of Egyptian history:

\begin{tabular}{lcc} 
Dynasty & Dates (B.C.) & Length \\
\hline 4th Dynasty & $2613-2494$ & 119 years \\
\hline 5th Dynasty & $2494-2345$ & 149 years \\
\hline 6th Dynasty & $2345-2181$ & 164 years \\
\hline 12th Dynasty & $1985-1773$ & 212 years \\
\hline 18th Dynasty & $1550-1295$ & 255 years \\
\hline 19th Dynasty & $1295-1186$ & 109 years \\
\hline 20th Dynasty & $1186-1059$ & 117 years \\
\hline 26th Dynasty (Saïtes) & $656-525$ & 131 years \\
\hline 27th Dynasty (First Persian Period) & $525-404$ & 121 years \\
\hline 31st Dynasty (Ptolomies) & $305-30$ & 275 years \\
\hline
\end{tabular}

Length of important Egyptian dynasties ${ }^{4}$

Indeed, the Ptolemaic Dynasty was the longest of all who reigned over the geographic space of ancient Egypt: 275 years (considering only the years between the basileia of Ptolemy I Soter and the death of Cleopatra VII). If we include in the score the years since the invasion / conquest of Egypt by Alexander (in 332 B.C.), when, however, technically, there was still no Lagid Dynasty ruling, this period of «Macedonian origin» would account for 302 years, which means more than three centuries. Neither the famous and often model 18th Dynasty, of the New Kingdom (with 255 years), nor the dynasty which marks the recovery of Pharaonic power in the Middle Kingdom, the 12th Dynasty (212 years) reached this length of time.

However, these were not three centuries of consistent history. Generally speaking, we can assume that each of the centuries of the Ptolemaic Dynasty denotes different «moments»: the 3rd century B.C. marked the implementation and affirmation of the Ptolemaic Dynasty; the 2nd century B.C. met repeated seditions, rebellions and revolutions in the capital, chôra, and the 1st century B.C. witnessed the direct intervention of Rome in the domestic affairs of Lagid Egypt.

\footnotetext{
${ }^{3}$ MANNING, 2010: 31, 65.

${ }^{4}$ MANNING, 2010: 67. The numeration of the dynasties is according to Manetho (except Dynasty 31 ). The length of reigns follows SHAW, 2000.
} 
Nevertheless, the durability and stability of its territory, despite the inevitable vicissitudes and vagaries of the political dynasty, put the Ptolomies ahead of the other two dynasties regarded by Egyptologists as the largest of its period (the twelfth and eighteenth dynasties). Like those, also the Lagid Dynasty is also remembered by the intense activity of its monarchs, by the profound political reforms introduced in the country and by the territorial expansion ${ }^{5}$.

The Ptolemaic Dynasty, centred on the king, around whom revolved the entire organisation of the state (personnel monarchy) and to whom should succeed, in principle, his eldest son (hereditary monarchy), was not only the longest dynasty of the Hellenistic states that followed Alexander, and that generally fell during the 2nd century and first half of the 1st century B.C. before the Roman domination - and Egypt resisted until the end of the 1st century B.C. - as it was the longest one that politically dominated the country of the Two Lands over its history. The Egypt of the Ptolomies was the last of the Hellenistic kingdoms to lose its independence.

If we add to the notion of durability, the observation that the Ptolemaic Dynasty was the richest, the most prosperous and the most active of the Hellenistic kingdoms, then one can easily understand its importance within the Egyptian history.

A second idea that is worth considering and may also, for its value, aid in the «rehabilitation» of this historical period and of the Lagid Dynasty is that the Ptolemaic Period is one of the largest take-overs of all Antiquity. The Ptolemaic governing actually had profound consequences, of long duration, on the history of Egypt in a strict sense and also resulted in the formation of a legacy of the ancient Egypt to the West, in the broader sense $e^{6}$.

This take-over is noticeable and was indelible in many areas: in economy (by creating a true urban economy and monetary policy, based on state monopoly), in administration (with the establishment of administrative units that simplified perception of taxes and financial and economic exploitation - eg.: nomoi / topoi / comoi, directed respectively by nomarcs, toparchs and comarcs, aided by their respective secretaries (basilikogrammateis, topogrammateis and komogrammateis) and by the many officials who joined the central administration, as dioiketes, the epistolographer, the hypomnematographer, the arquidicasta, the epistrategos, the nomos strategos, and so on, in a rigid, large, but effective bureaucratic and administrative chain ${ }^{7}$ ), in culture and in science (with the founding of exclusive institutions in the capital of Alexandria, like the Museum and the Library, research and academic training centers, which generated the greatest figures of the human spirit in areas such as Medicine, Astronomy, Geography, Geometry, Matemathics, Physics, Literature, Textual Criticism, Philology, Grammar, Lexicography, and so on).

\footnotetext{
${ }^{5}$ MANNING, 2010: 68-69.

${ }^{6}$ MANNING, 2010: 32.

${ }^{7}$ BERNAND, 1998: 202, 203; BURKHALTER, 1992: 190; PRÉAUX, 1939: 448-449.
} 
The Museum, «temple of Muses», founded by Ptolemy I Soter, became forever associated with the development of science in the Hellenistic Period. Among its early directors were Demetrios of Phaleron (the "philosopher of power» behind the design of the Museum) and Straton of Lampsakos, disciples of Aristotle, defenders and promoters of the universal knowledge that his teacher proclaimed ${ }^{8}$. Demetrios of Phaleron was a member of the Peripatetic school and former governor of Athens (317-307 B.C.). Expelled from power in Athens, he took refuge at the court of Ptolemy I, to whom he became a dedicated adviser.

The ancient library of Alexandria was one of the most ambitious and exciting intellectual adventures of human history. Built by order of Ptolemy I Soter (305-285 / 283 B.C.), also with the direct collaboration of Demetrios of Phaleron (350-280 B.C.), who took to Alexandria the Aristotelian ambition of universal knowledge, the library intended to accommodate, by royal command, writings from all existing cultures. Among his most famous librarians, the Library was attended by distinguished men of genuine encyclopedic spirit, as Zenodoto of Ephesus, Apollonios of Rhodes, Eratosthenes of Cyrene, Aristophanes of Byzantium and Aristarchus of Samothrace. As central depot of ancient knowledge and Hellenistic producer of culture, it had the largest collection of books gathered so far (400,000 volumina or papyrus rolls, according to Callimachus of Cyrene). It became the largest centre of study and Greek culture?

In the field of knowledge, the list of great intellectuals who lived, worked or passed through Alexandria is vast. Some continue to be among the greatest thinkers, scientists and technicians of all time: Euclid of Alexandria, Eratosthenes de Cyrene, Hipparchus of Nicaea, Aristarchus of Samos, Archimedes of Siracuse, Aristophanes of Bizantium, Apollonios of Rhodes, Apollonios of Perge, Straton of Lampsakos, Herophilos of Chalkedon, Erasistratos of Kos, Philetas of Kos, Callimachus of Cyrene, and so on ${ }^{10}$.

Almost all great scholars and artists from centuries III to I B.C., from Alexandria and from all over the Hellenistic world, were invited to the Library and passed by the pros tou Aigypton Ptolemaic Alexandria and their achievements have earned fame and appreciation for the city («city of all knowledge»), marking it, so to say, forever in the collective imagination as the world capital of knowledge («capital of the books», «capital of memory») and as an intellectual centre of the Hellenistic era, supplanting the classical Athens, with a key role in shaping the coming times ${ }^{11}$. Knowledge meant power ${ }^{12}$.

\footnotetext{
${ }^{8}$ MOSSÉ, 1992: 83-92; BERNAND, 1996: 112-118; EL-ABBADI, 1998: 112.

${ }^{9}$ BERNAND, 1996: 118-121; SERAGELDIN, 2002: 25; NEWMAN, 1997: 129-132; LEVET, 1997: 45-58; GÓMEZ ESPELOSÍN, PÉREZ LARGACHA, 1997: 74-91; GÓMEZ ESPELOSÍN, 1997a: 163-185; GÓMEZ ESPELOSÍN, 1997b: 63-81; ARGOUD, 1998: 118-133; BING, 1998: 133-135; EL-ABBADI, 2002: 47-49.

${ }^{10}$ SALES, 2006: 57-76; SALES, 2008: 60; MOSSÉ, 1992: 83-92; LALLOT, 1992: 93-99; JACOB, 1992: 100-112, 113-127.

${ }^{11}$ Alexandria, home of the king and his court (aulè) and of the central administration, where were shared all the hardships and all the glories of the Ptolemaic monarchy (BERNAND, 1996: 69, 72, 75).

${ }^{12}$ EMPEREUR, 2001: 40.
} 
As Jacob and Polignac wrote, «au-delà de la singularité des œuvres et des talents, il y a une dimension collective du travail intellectuel alexandrin, où chaque nouvel auteur apporter ses propres améliorations, ses corrections, ses prolongements a l'oeuvre d'un prédécesseur.... ${ }^{13}$.

The cultural dynamics of cosmopolitan Alexandria and all the shiny and intense activity of its intellectuals was only possible, however, due to the "patronage» of voluntary and committed Ptolomies: the first Ptolemies (Ptolemy I, Ptolemy II Philadelphus and Ptolemy III Euergetes I) supported these scholars as pensioners of the state. Their intellectual activity was developed under patronage and under the Ptolemaic royal treasury ${ }^{14}$.

For this, the Ptolemaic kings used the ingenious mechanism of «financial control» that they had at their disposal: firstly, because they had direct access to mines and sources of raw materials, they coined currency in gold, silver and bronze, and put it in circulation around all the territory under imperial domination. Due to the gold mines of Nubia, the traditional «Gold Country» for the Egyptian, Ptolemaic Egypt held an enviable position in the international context of the Hellenistic Period, which allowed for the coinage to he based on gold. Their coinage in gold was indeed the most abundant and most sumptuous in the Hellenistic world (at least until the 6th century B.C.). This does not mean, however, that the Ptolemies did not make currency in other metals. The mines of silver and copper from Cyprus and Syria-Phoenicia also contributed for that. The main units used were the stater of gold, the silver tetradrachm and the obol of bronze. The standard coin was the silver tetradrachm which was equivalent, as its name indicates, to 4 drachms, or 24 obols. Besides these, there were the hemidrachms, the didrachms, the tridrachms, the pentadrachms, the octodrachms, the double octodrachms and the dekadrachms ${ }^{15}$.

Aiming to control the money supply in Egypt to establish an effective monetary and commercial imperialism, they, on the other hand, ensured attractive prices in the international market. This procedure was only made possible by the establishment of monopolies for many products made in Egypt or entering the capital Alexandria (wheat, papyrus, ivory, perfumes, textiles, art objects, so on.), through the privileged access they had to many raw materials and the strong economic and financial coercion exerted on Egyptian domestic economy.

Concomitantly, they forbade the circulation in the imperial territory of any currency other than the one they coined, demanding to all traders who came to Alexandria the currency exchange of any other money brought from abroad. Having adopted a standard lighter for their silver and bronze coins (weight Ptolemaic: 14, $25 \mathrm{~g}$ ) and trivialized the Attic weight used in most commercial and financial transactions of the central-eastern Mediter-

\footnotetext{
${ }^{13}$ JACOB, POLIGNAC, 1992: 19.

${ }^{14}$ JACOB, POLIGNAC, 1992: 17.

${ }^{15}$ SALES, 2005: 232, note 23; MØRKHOLM, 1991.
} 
ranean $(17.20 \mathrm{~g})$, they achieved a difference of $2.95 \mathrm{~g}$ in each currency $(17.15 \%$ less metal per coin).

Ptolemy I Soter originally coined following the pattern of Rhodes and Phoenicia and later, ca. 312/310 B.C., adopted the one from Cyrene (14.25 g of silver). This was a deliberate move on the dissociation of Egypt from the rest of the Hellenistic world, with the aim of building an economic autarchy, then consolidated politically, in 305 B.C., with the adoption of the title basileus. Ptolemy III Euergetes I would eventually adopt the standard weight of Attica, after nearly 60 years of distinct practice ${ }^{16}$.

Giving their money a lower weight, the Ptolomies consummated a rupture in relation to other currencies in circulation in the area of the central-eastern Mediterranean and implemented a new and elaborate system, clearly in favor of the State ${ }^{17}$.

The Ptolemaic state, due to the series of held monopolies and its role as a leading exporter, played with the ratio of gold / silver coin, introducing an element of trust in local transactions, and ensuring all merchants that the Lagid state coin (lighter) had the same purchasing value of money delivered (heavier), despite the lower amount of metal it contained. In doing so they raised extraordinary amounts of metal and wealth in coinage and in foreign exchange transactions that paved the way to, among other things extraordinarily productive intellectual work in Alexandria. The intelligent taxation of the first Ptolemies, along with the overvaluation of mintage, undoubtedly represented a particularly successful case of funding for scientific and cultural research activities.

It should also be pointed out, since recent research has highlighted this matter, that the Ptolomies are among the most successful rulers of the long history of Egypt and that their government had, at various levels, profound effects on Egyptian and East-Mediterraneanhistory. A brief overview of three centuries of Lagid domination will allow us to see the important and multifaceted reigns of these kings, their successes and failures and their consequences.

The first of the Ptolemaic kings, the founder of the dynasty, Ptolemy I Soter I (305-285 / 283 B.C.), the only one of Alexander the Great's diadochoi to die of natural causes with over 80 years old, one of the generals responsible for Alexander's co-conquests and the remarkable extent of his empire, "the self-made man who became king only through his merit» ${ }^{18}$, defended, through his military successes, «their» satrapies (with a corresponding increase of the Lagid territories and possessions in Ionia, Lycia, Pamphylia, Cilicia, Cyprus, Phoenicia, Syria, Palestine and Cyrenaica) ${ }^{19}$. In 302-301 B.C., Ptolemy I seized Coele Syria; in 302 B.C., he attacked Jerusalem (302 B.C.); following the Battle of Ipsus (301 B.C.), he

\footnotetext{
${ }^{16}$ MØRKHOLM, 1991: 233.

${ }^{17}$ MØRKHOLM, 1991: 233.

${ }^{18}$ BINGEN, 2007: 15, 27.

${ }^{19}$ BAGNALL, 1976.
} 
governed Coele Syria; in 295-294, reintegrated Cyprus in the Ptolemaic Empire and, in 285 B.C., he took leadership of the League of the Islands.

Ptolemy I was also responsible for the modernisation and rationalisation of the forms of organization inherited from the Egyptian pharaohs and the great Persian kings, as well as for the power and cohesion that the Lagid state achieved during his reign. When it comes to "Lagid thalassocracy in the eastern Mediterranean», his role and his political action are unavoidable. Ptolemy I was the first great diplomat, strategist, leader and administrator of the Ptolemaic dynasty, with intelligence, vision and a draft policy for the independence of Egypt $^{20}$.

In Egypt, Ptolemy I organized the country (combining the heritage of the local tradition with Hellenic rationalism), set the capital in Alexandria, the city founded by Alexander the Great, which gave it a considerable urban commercial and intellectual development, founded the city of the Ptolemies in Upper Egypt, that supplanted the millenary Memphis, confirmed the Lagid authority in southern Egypt, and introduced the worship of Sarapis (identified with Osiris-Apis) as the multicultural patron of Alexandria ${ }^{21}$.

The introduction of the cult of Sarapis in the capital city of the Ptolemies - «the masterpiece of statecraft», as Budge called $i^{22}$ - responded to the need for intercultural harmonisation of the two most important groups of people in Alexandria and was an important factor in overcoming the antithesis of losers/winners, old/modern, native/foreign undertaken with the Greek occupation of Egypt that posed one of the biggest problems to political power, at the turn of the 4 th century B.C..

Ptolemy I's ex-nihilo creation of a new god allowed him to regulate the complex ethnic and cultural society of Alexandria. This had a deep ideological meaning, especially for such a cosmopolitan city, characterised by its syncretism and its cultural-religious symbio$\operatorname{sis}^{23}$.

His son, the «victorious king», the magnificent Ptolemy II Philadelphus, who rose to power at the age of 25 , in 285 B.C., after an intelligent and voluntary abdication of his father ${ }^{24}$, and who reigned until the age of 63 (246 B.C.), went hard on his father's policy, increasing the Lagid empire. With the aid of Apollonio, his assets dioiketes (finance minister), he organised the economy (establishing the royal monopolies), modernised agriculture (especially in the Fayum region) and restored the link between the Nile and the Red Sea (ca. 270-269 B.C.), and acted as protector and promoter of the arts and the letters (building the Museum and Library).

\footnotetext{
${ }^{20}$ BINGEN, 2007: 23, 24; SALES, 2005: 41.

${ }^{21}$ MANNING, 2010: 106; STAMBAUGH, 1972.

${ }^{22}$ BUDGE, 1902: 187.

${ }^{23}$ SALES, 2007: 377.

${ }^{24}$ During his last years in power (285-283 B.C.), Ptolemy I planned to crown his youngest son, Ptolemy II (son of his second wife, Berenike I), at the expense of his eldest son, Ptolemy Ceraunus (fruit of his marriage with Eurydike).
} 
It was Ptolemy II who endowed Egypt with a judicial organisation that took into account the ethnic and cultural duality of the country: the courts for Hellenic immigrant (dicasteres) and autochthons (laocrites, «people's courts»), subject to royal justice, which the sovereign exercised alone or through their chrêmatistai. His reign was also marked by the implementation of a rigorous system of financial administration. Ptolemy II was a central figure in the history of the dynasty. Under his rule, Alexandria became the centre of the world and attained enormous intellectual prestige. It was during the reign of Ptolemy II that the Pharos of Alexandria (283 B.C.) opened; that the Septuaginta (the Greek translation of the Bible) was carried out; that the dynastic cult (worship of Greek) in honor of Ptolemy I was established; and that Manetho wrote a three-book history of Egypt in Greek (Aegyptiaca), divided in thirty dynasties, that modern Egyptology continues to use as a reference to the chronological history of the pharaohs. It does not seem surprising, then, that the second of the Ptolemies was considered the most prosperous and cultured Hellenistic king of his time ${ }^{25}$.

The Ptolemaic empire reached its peak with Ptolemy III Euergetes I (246-221 B.C.), Ptolemy II's son with his first wife, Arsinoe I. Having reached the throne at the age of 30, Ptolemy III united Cyrenaica and Egypt by marrying Berenike II, daughter of King Magas of Cyrene, and achieved several victories in Asia (Third Syrian War) against the neighbors Seleucids, which propelled the Lagid empire to its peak. He then became master of all western Asia.

In 241 B.C., the Lagid state was immensely rich and powerful, assuming the leadership of the Achaean League, and its borders extended to the Euphrates (246-241 B.C.). Owing, however, to a native Egyptian revolt against the Ptolemaic regime, Ptolemy III was forced to interrupt his eastern campaign.

The Lagide power faced its first problems with Ptolomy III: the administration could not gather the necessary income, given the reluctance of peasants and recurred to currency manipulation in order to remedy the situation, due to all the pressure groups. At the time of Ptolemy III, the Library of Alexandria had reached the impressive number of 490,000 volumina.

The first three Lagid, therefore, developed a major foreign policy (according to Polybius, Egypt became an impregnable bastion) and became powerful players in a new golden age in the Mediterranean, with Alexandria as the centre of the world economy this time. It was the deployment phase and affirmation of the Ptolemaic Dynasty in the international arena.

The power was, however, fleeting, for the human, military and leadership means were scarce, and the reign of Ptolemy IV Philopator (221-205 B.C.), pharaoh of «sinistre réputation auprès des historiens ${ }^{26}$, full of vices and personal and political flaws in the mouth of

\footnotetext{
${ }^{25}$ CHAUVEAU, 1992: 138.

${ }^{26}$ LEFEBVRE, 2009: 91.
} 
Polybius, already showed the first signs of paralysis and decay ${ }^{27}$. When Antiochus III of Syria (Fourth Syrian War, 219-217 B.C.) sought to retrieve Phoenicia and Palestine, the Lagid king responded with the unusual recruitment to the phalanx of the army of 20,000 Egyptian soldiers (machimoi), with which it resisted the Seleucid's pretensions (Battle of Raphia, $22^{\text {nd }}$ June 217 B.C.). The right to bear arms to defend the country, allowed to the autochthons for the first time, brought unexpected and serious consequences (the «paradoxical effect»). Conscious of their strength, the Egyptians machimoi believed that they were no more to remain under the foreign power and started claiming more political and social participation ${ }^{28}$.

Internal disturbances increased with the revolt of the Thebaid, in Upper Egypt (known as the dynastic schism of Horwennefer and Ankhwennefer, two Nubian princes, declared pharaohs between 206-200 and 200-186 B.C. respectively), and bad agricultural $\mathrm{crops}^{29}$. The Lagid-Alexandrian power had to compromise with certain requirements of the autochthons of the South. Even the Egyptian priests of Thebes took advantage of the situation and supported the rebels against Alexandrian power ${ }^{30}$. This shows how the Lagid power outside of Egypt was weakening.

The reign of Ptolemy V Epiphanes (205-180 B.C.) - who came to power at the age of 5-6 and died at the age of 29 - was also marked by the intensification of social problems in the Delta and by uprisings in Alexandria, one of them in which the raged mob lynched Agathokles, the royal advisor who had seized power before the king's coming of age and murdered his mother, queen Arsinoe III.

Externally, in the Fifth Syrian War against Antiochos III (202-195 B.C.), the king of Egypt lost the territories of Coele, Syria, Gaza and Judah (202-201 B.C.) escaping him, while internally he eventually controlled the region of Thebes (199-198 B.C.), putting an end to the insurgent movement of Thebaïd and restoring the Lagid authority in 186 B.C. While he could sustain «the time of the riots» (Rosetta Stone, line 20) of the secessionist movement for independence of Upper Egypt, Ptolemy V could not, however, prevent the dismemberment of his empire: with the permanent loss of both Syria and Palestine, the independent Lagid empire collapsed and fell into Rome's control.

Ptolomy V Epiphanes' reign was important for three other things: on the one hand, the king's marriage to Cleopatra I of Syria (at Raphia in the winter of 194-193 B.C.), thus introducing, for the first time, exogenous blood in the Lagid Royal House; secondly, for the first time in Egyptian history, the Lagid pharaoh was crowned directly by Egyptian priests,

\footnotetext{
${ }^{27}$ PRÉAUX, 1965: 364-375.

${ }^{28}$ SALES, 2010b: 158, 159.

${ }^{29}$ SALES, 2010a: 427.

${ }^{30}$ HÖLBL, 2001: 115; SALES, 2010a: 428 and 2010b: 160, 162; LLOYD, 1982: 33-55.
} 
as shown in the official document, dated 27 March 196 B.C., recorded in Rosetta Stone ${ }^{31}$; finally, the Lagid lost numerous international territories (at the excepttion of Cyprus) ${ }^{32}$.

With the definitive loss of both Syria and Palestine, the independent Lagid Empire collapsed and fell into Roman control. With the repeated tumults, rebellions and revolutions in the capital and in the chôra, and the loss of territory conquered by the first three rulers of the dynasty, the 2nd century B.C. marks the end of the glorious era of the Lagid Dynasty. From that moment forward, Egypt was never able to regain the brilliance of the past. However, it tried to maintain its political independence.

The reigns of Ptolemy VI Philometor (180-164, 163-145 B.C.) and his brother Ptolemy VIII Euergetes II (170-163, 145-116 B.C.) were marked by open guerrillas and constant alternation of rulers in power, the progressive weakening of royal power, an increase in intrigues among the royal court members, the popular uprisings of the indigenous and the intervention of foreign powers in Egypt. In the Sixth Syrian War (171-168 B.C.), Antiochus IV Epiphanes (Cleopatra I's brother and therefore Ptolemy VI and Ptolemy VIII's uncle) crossed the Coele Syria (which the Lagide had definitely lost to the Seleucids in 145 B.C.), captured Antioch, robbed the Temple of Jerusalem and defeated the Ptolemaic army near Pelusion. In 163/162 B.C., Ptolemy VIII appeared before the Roman Senate in order to obtain the government of Cyprus. Ultimately, the degeneration and decay of the Lagid Dynasty accelerated: the Egyptian empire finally lost its unity. During his reign, Ptolemy VIII ordered the suspension of Alexandria's intellectual life, as well as a purge of the scholars in 144 B.C. Brutal action was taken against Jews settled in the city.

However, the period in which Ptolemy V and Cleopatra I's sons governed were marked by extensive constructions and decorations in the Egyptian temples of the Upper Egypt, which are still today the focus of attention of millions of tourists and a starting point for the virtual reconstruction of what many call the «times of ancient Pharaohs» ${ }^{33}$.

The death of Ptolemy VIII triggered a series of joint kingdoms and endless quarrels between the dynastic queens Cleopatra II, Cleopatra III and the sons of Ptolemy VIII (Ptolemy IX Soter II, Ptolemy X Alexander I and Ptolemy XI Alexander II), which ended with the exile of Ptolemy X in Asia Minor and the murder of Ptolemy XI in 80 B.C. by Alexandrian rebels. Ptolemy XI Alexander II was the last king of the authentic Ptolemaic lineage. One of his testaments compromised the inheritance of his direct successors and made Rome the heir of his genealogic power ${ }^{34}$. Some authors see this political will in favour

\footnotetext{
${ }^{31}$ The trilingual text preserved in the Rosetta Stone is a copy of a decree issued by the Supreme Council of Priests, meeting at Memphis, giving an account of the measures taken and promulgated Ptolemy V Epiphanes on 27 ${ }^{\text {th }}$ March 196 B.C. (JOHNSON, 1986: 70-84).

${ }^{32}$ In the Battle of Panion (212 B.C.), for example, Antiochus III the Great of Syria, attacked Egypt and took possession of Palestine (Coele Syria, Gaza and Judah) which, thus, fell into Ptolemaic control.

${ }^{33}$ Where the temples of Horus at Edfu, Hor-Wer / Sobek in Kom Ombo, and Isis in Philae are set.

${ }^{34}$ VAN'T DACK, 1989: 23, 156-161.
} 
of Rome as Ptolemy X Alexander I's iniciative and not Ptolemy XI Alexander II, but it seems that the document was forged in Rome to justify their increasing political meddling in Egypt's affairs.

With no heirs, the Egyptian throne passed to Ptolemy XII Neos Dionysus Aulete (8058, 55-51 B.C.). He came to power after the assassination of Ptolemy XI, but at the time he was not accepted by Rome. In order to be recognised by the Roman Senate in 58 B.C., he had to spend large sums of money (most of which would go directly into the hands of Julius Caesar). The Romans voted for the transformation of Cyprus into a Roman province, seizing the island, which led to the suicide of the king of Cyprus, his brother (also named Ptolemy). This, in turn, triggered anger and popular pressure of the Alexandrians, forcing Ptolemy XII into exile in Rome (58-55 B.C.), while his daughter Berenice IV (from his marriage with Cleopatra VI Tryphena) came to power in Alexandria. It was only in 58 B.C., after 22 years of de facto government, and heavy bribery of Romans politicians, that Ptolemy XII was de iure considered amicus et socius populi Romani. After new commitments, loans and bribes, the Roman armies restored Ptolemy XII to the Egyptian throne (55-51 B.C.). Objectively, the Lagide monarchy became, then, a puppet in the hands of the Romans.

The «epilogue of Ptolemaics», between 51 and 30 B.C., with Cleopatra VII, Ptolemy XIII, Ptolemy XIV and Ptolemy XV, is the culmination of the disappearance of the Lagid Dynasty against Rome, the new power in the Mediterranean territory.

In his testament, Ptolemy XII determinated a «co-regency» between Ptolemy XIII Philopator (aged 10) and his sister, the famous Cleopatra VII Thea Philopator (then 17). Julius Caesar entered Alexandria as the executioner of the testament (in pursuit of Pompey) and arbitrated the conflict between Ptolemy XII's children and Cleopatra VII's alliance with Ptolemy XIV.

Any alliance between Cleopatra VII and the «lords of Rome» (first Julius Caesar, until 44 B.C., and then Mark Antony, 41-30 B.C.), using all the means she had at her disposal, including her own personal charms, was the desperate attemp of a representative of the Royal House of the Ptolemies to maintain her political and territorial independence.

The Battle of Actium (September 2 ${ }^{\text {nd }}, 31$ B.C.), Octavian's victorious entrance in Alexandria and Antony and Cleopatra VII's suicides were different moments of the same reality: they were the confirmation of the end of the imperial grandeur of the Ptolemies, the death of their aspiration to world domination. August $29^{\text {th }} 30$ B.C. can thus be considered the date that marks the final statement of the Ptolemaic empire.

Still, the way the Ptolemaic sovereigns of the 1st century B.C. acted, sometimes more indolent or more tenacious, more pragmatic or more ambitious, allowed for the durability of their dynasty in comparison with the other dynasties of the Hellenistic kingdoms. The Ptolemies' Egypt was, therefore, as has already been stated, the last of the Hellenistic kingdoms to lose its independence. 


\section{CONCLUSION}

Ptolemaic Egypt occupies a prominent and privileged place in the history of ancient Egypt, not only because of its specific geographic and climatic conditions, which helped save many documents, but also due to the forms and rules of the bureaucratic and political, economic and financial and ideological-cultural management decided and implemented by the Ptolemies from the scheme set up by the previous centuries of pharaonic administra$\operatorname{tion}^{35}$. The Ptolemies turned Egypt into a «family affair», giving the country original institutions. They operated under their new plans, which were substantially different from the ones practiced in classical Greece ${ }^{36}$.

Instead of considering Egypt's Lagid Dynasty as a break with the glorious past of the land of the Pharaohs, we should rather consider the Ptolemaic Period as a part of the Egyptian history - and bright and glorious in many aspects ${ }^{37}$. The Ptolemaic political power must be given credit for the way it established cultural institutions of reference in the city (especially the Museum and the Library) and also for the protection given to scientists, poets and philosophers.

The Ptolemies intelligently used their relationship with the local Egyptian tradition, namely with the local priests, always attempting to maintain and ensure their political domination over Egypt. Perhaps, that is why the Ptolemaic Dynasty lasted longer than any other sovereignty founded by the successors of Alexander the Great. Furthermore, although experiencing some internal unrest, the Ptolomies were able to do so with less violence than any of their Hellenistic counterparts ${ }^{38}$.

Acknowledging and recognizing the «special features» of their performance over the three century-long dynasty is important if we were to reduce and, hopefully, eliminate the ignorance and contempt that surrounds the study of the Ptolomies and perhaps, it may even increase the appreciation of the Ptolomaic history, thus rehabilitating its, in many cases, unloved actors.

\footnotetext{
${ }^{35}$ WELLENDORF, 2008: 34.

${ }^{36}$ BERNAND, 1998: 199.

${ }^{37}$ MANNING, 2010: 33-34; SALES, 2005: 27-28.

${ }^{38}$ WELLENDORF, 2008: 34.
} 